\title{
Does using constrained acetabular component really limit hip range of motion?
}

\section{Kısıtlayıcı asetabular komponent kullanmak kalça eklem hareket açıklığını gerçekten azaltır mı?}

\author{
Zekeriya Ersin CELEN ${ }^{*} \square$, Bülent OZKURT ${ }^{2} \square$, Ali UTKAN ${ }^{3} \square$, Aydın ARSLAN ${ }^{4} \square$, \\ Tuba Umit GAFUROGLU ${ }^{5}$, Filiz ESER ${ }^{6} \square$
}

'Yalova Public Hospital, Department of Orthopaedics and Traumatology, Yalova / TURKEY

${ }^{2}$ University of Health Sciences, Ankara State Hospital, Department of Orthopaedics and Traumatology, Ankara / TURKEY ${ }^{3}$ University of Health Sciences, Ankara State Hospital, Department of Orthopaedics and Traumatology, Ankara / TURKEY ${ }^{4}$ Medical Park Avcilar Hospital, Department of Orthopaedics and Traumatology, Istanbul / TURKEY

${ }^{5}$ University of Health Sciences, Ankara State Hospital, Department of Physical Theraphy and Rehabilitation, Ankara / TURKEY

${ }^{6}$ University of Health Sciences, Ankara State Hospital, Department of Physical Theraphy and Rehabilitation, Ankara / TURKEY

\begin{abstract}
Aim: In surgical treatment of instability, constrained acetabular inserts are frequently used in hip arthroplasty. However the reasons why surgeons avoid constrained acetabular components are the concern of an increased rate of loosening possibly due to impingement and the concern of decreased range of motion. This study aims to investigate the influence of constrained acetabular insert usage on hip range of motions and functional results.
\end{abstract}

Material and Methods: Twenty-eight patients who needed revision hip arthroplasty were included. Patients were divided into two groups according to acetabular insert used in surgery (constrained and non-constrained). Mean follow-up period was $61 \pm 7$ months (range, 50-74) in constrained group and 59 \pm (range, 50-72) in non-constrained group. Hip range of motion and harris hip scores were recorded pre-operatively and at final follow-up.

Results: The final avarage flexion, abduction, adduction, external rotation and internal rotation was respectively $78^{\circ} \pm 15^{\circ}$, $43^{\circ} \pm 4^{\circ}, 28^{\circ} \pm 3^{\circ}, 30^{\circ} \pm 7^{\circ}, 19^{\circ} \pm 8^{\circ}$ in constrained group $(n=15)$ and $75^{\circ} \pm 14^{\circ}, 40^{\circ} \pm 6^{\circ}, 26^{\circ} \pm 5^{\circ}, 30^{\circ} \pm 12^{\circ}, 17^{\circ} \pm 6^{\circ}$ in non-constrained group $(n=13)$. The difference between groups was not statistically significant. Harris hip score increased in both groups and there was no significant difference between groups $(p=0.730)$.

Conclusion: Findings of this mid term study showed that hip range of motions and functional results in patients with constrained acetabular inserts are not inferior than the patients with non-constrained inserts.

Keywords: Articular range of motion; total hip arthroplasty; joint instability

Corresponding Author*: Zekeriya Ersin Çelen, Yalova Public Hospital, Department of Orthopaedics and Traumatology, Yalova / TURKEY E-posta: drersincelen@gmail.com

ORCID: 0000-0001-5229-0802

Recevied: 31.08 .2020 accepted: 10.04.2021

Doi: $10.18663 /$ tjcl.788010 


\section{Öz}

Amaç: Kısıtlayıcı asetabular insertler, instabilitenin cerrahi tedavisinde sıklıkla kullanılmaktadır. Bununla birlikte, gevşeme sıklığını artıracağı ve kalça eklem hareket açıklığını azaltacağı endişesi ile cerrahlar arasında daha az tercih edilmektedir. Bu çalışmanın amacı, kısıtlayıcı asetabular komponent kullanımının kalça eklem hareket açıklığı ve fonksiyonel sonuçlar üzerindeki etkisinin incelenmesidir

Gereç ve Yöntemler: Revizyon kalça artroplastisi uygulanan 28 hasta çalışmaya dahil edildi. Hastalar kullanılan insert

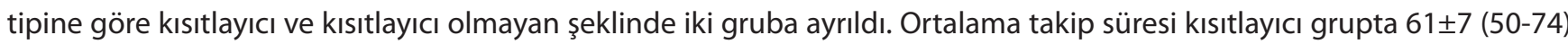

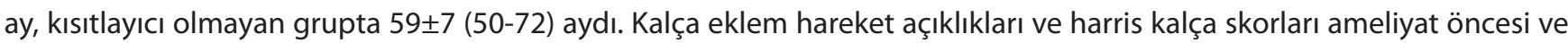
sonrası son kontrolde kaydedildi.

Bulgular: Ortalama fleksiyon, abdüksiyon, addüksiyon, dış rotasyon ve iç rotasyon değerleri kısıtlayıcı grupta ( $\mathrm{n=15}$ ) sırası ile $78^{\circ} \pm 15^{\circ}, 43^{\circ} \pm 4^{\circ}, 28^{\circ} \pm 3^{\circ}, 30^{\circ} \pm 7^{\circ}, 19^{\circ} \pm 8^{\circ}$ iken, kısıtlayıcı olmayan grupta $(n=13) 75^{\circ} \pm 14^{\circ}, 40^{\circ} \pm 6^{\circ}, 26^{\circ} \pm 5^{\circ}, 30^{\circ} \pm 12^{\circ}$, $17^{\circ} \pm 6^{\circ}$ idi. Gruplar arasındaki fark istatistiksel olarak anlamlı değildi ( $\left.p>0.05\right)$. Harris kalça skorları her iki grupta da ameliyat öncesine göre anlamlı artış gösterdi, gruplar arasında anlamlı farklılık yoktu ( $p>0.05)$.

Sonuç: Bu çalışmanın bulguları, kısıtlayıcı asetabular insert kullanılan hastalardaki kalça eklem hareket açıklıkları ve fonksiyonel sonuçların, orta dönemde, kısıtlayıcı olmayanlara göre daha az olmadığını göstermiştir.

Anahtar Kelimeler: Eklem hareket açıklığı; total kalça artroplastisi; eklem instabilitesi

\section{Introduction}

Total hip replacement is one of the most satisfying procedures in orthopaedics [1]. On the other hand, in the course of time, hip prothesis may fail because of several reasons. Today hip revision arthroplasty is more needed since more total hip arthroplasty procedures are being performed especially on younger patients [2].

One of the most common problems after revision hip surgery is instability [3]. The reported incidence varies up to $35 \%$ after revision arthroplasty [4]. Although instability can successfully be treated conservatively, in many instances surgerymay be required, especially in recurrent instabilities [5]. Surgical options include proper readjustment of acetabular and femoral component orientation, exchange of modular components such as femoral head and acetabular liner, usage of larger femoral head, soft tissue reinforcement, advencement of greater trochanter and using a dual mobility implant or a constrained component [6-8].

Constrained acetabular component prevents instability by holding femoral head captive within the socket $[8,9]$. It is an option for patients with recurrent dislocation, intraoperative instability, instability of unknown etiology, abductor deficiency, neuromuscular and cognitive disorders $[10,11]$.

There have been concerns about constrained components if there is any decreasing effect on hip range of motion (ROM)
[10-14]. However, there is no study comparing in vivo hip ROM of constrained acetabular components with those of nonconstrained ones. Thus this study was designed to compare ROM and functional score of the patients operated using constrained with non-constrained components.

\section{Material and Methods}

Between November 2013 and November 2015, patients who was in need of revision hip arthroplasty and admitted to Ankara Numune Training and Research Hospital were included in this prospective non-randomized controlled study. This research has been approved by the institutional review board of the authors' affiliated institutions and all patients provided written informed consent.

There were 46 patients hospitalized to our hospital for revision hip arthroplasty in this period. 6 re-revision patients were excluded. For constrained acetabular components, only $36 \mathrm{~mm}$ femoral head was the available choice. So, in non-constrained group, 12 patients that necessitated femoral head size other than $36 \mathrm{~mm}$ were excluded. Finally, 15 patients were treated with constrained acetabular component while 13 patients were treated with non-constrained acetabular component.

Using either constrained or non-constrained component was decided intra-operatively according to hip stability and integrity of abductor muscles. 
All operations were performed by same surgeon, on supine position, through anterolateral skin incision. Cementless arthroplasty was performed in all patients. Freedom acetabular inserts were used in the constrained group (Figure $1 \mathrm{a}, \mathrm{b})$. Exceed ABT acetabular shell system with E1 Ringloc- $X$ liner or E1 tapered liners were used in the non-constrained group (Biomet, Warsaw, USA). (Figure $2 \mathrm{a}, \mathrm{b}$ )

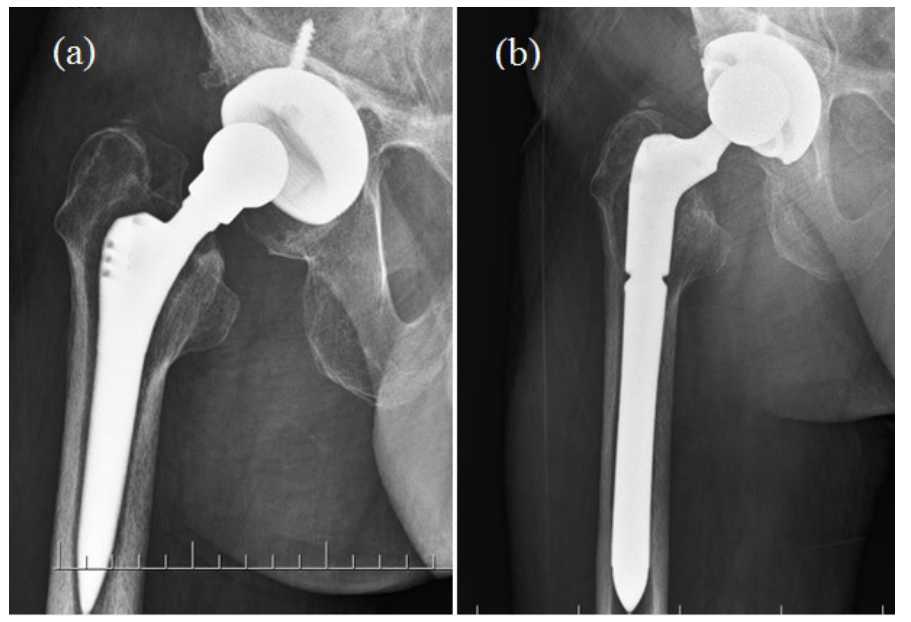

Figure 1 a-b: Pre-operative and one year post-operative radiographs of a 69 years old male patient that constrained component is used.

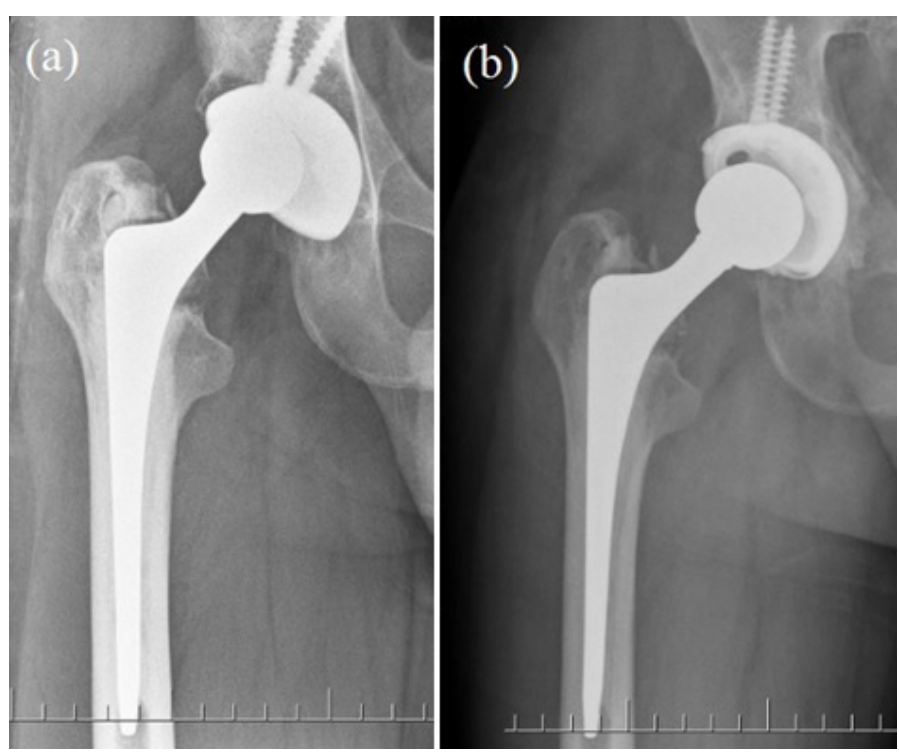

Figure 2 a-b: Pre-operative and one year post-operative radiographs of a 39 years old male patient that non-constrained component is used.

Six patients (three from each group) underwent two-staged surgery. We determined infection in these patients, extracted infected implants, debrided infected tissues and filled spaces with a spacer. After six weeks the sedimentation and CRP values returned to normal, we performed second stage surgery and implanted new prothesis. Defects were covered with bone grafts in three of 28 patients (one from constrained and two from non-constrained group).

Passive hip ROMs and harris hip scores were calculated pre-operatively and at final follow-up. ROM was measured with a manuel goniometer. Acetabular inclination angles were recorded measuring the angle between a line through the long axis of the cup ellipse and the inter-teardrop line on post-operative anteroposterior radiographs [15]. Acetabular anteversion angles were measured according to the Lewinnek's method on post-operative anteroposterior radiographs [15]. Anteroposterior and lateral X-ray views of the each hip were reviewed to assess the sign of loosening or wear of the prosthetic implant as Shrader suggested [16].

A peri-operative dose of cefazolin (Cezol, Turkey) was administered 30 minutes before the surgery and $2 \mathrm{gr}$ throughout the first day. Subcutaneous low molecular weight heparin $(0.4 c c, 1 \times 1)$ (Enox, Turkey) was given for six weeks for deep vein thrombosis and pulmoner embolism prophylaxis. Aspirative drain and pillow between the legs were used for all patients. Patients were hospitalized 7-11 days (2-4 days preoperative and 5-7 days post-operative). No leg immobilization was applied post-operatively and physical therapy was continued for six weeks.

\section{Statistical analysis}

Statistical anaylsis was performed using PASW Statistics for Windows (version 18, USA). Normal distribution of the parameters in each group was screened with Shapiro-Wilk test. Mann Whitney $\mathrm{U}$ test was used to compare groups. A p-value $<0.05$ was considered statistically significant.

\section{Results}

The baseline characteristics were comparable in the two groups (Table 1). Constrained group had higher hip ROM (flexion, abduction, adduction, external rotation (in extension) and internal rotation (in extension)) when compared with non-constrained group, however the difference between groups was not significant (Table 2).

Harris hip scores increased in both groups when compared with pre-operative values but there was no significant difference between groups $(p=0.730)$. In the constrained group harris hip score improved from a mean of $41.80 \pm 17.82$ (range, 5-63) pre-operatively to $84.21 \pm 13.95$ (range, 50-99) at the last follow-up and from $41.85 \pm 14.25$ (range, 23-70) to $86.38 \pm 8.94$ (range, 70-99) in the non-constrained group.

Mean post-operative avarage acetabular inclination angle was 


\begin{tabular}{|c|c|c|c|}
\hline & Constrained group $(n=15)$ & Non-constrained group $(n=13)$ & $P$ values \\
\hline Age, years & $65.80 \pm 7.66(53-83)$ & $58.69 \pm 11.74(39-73)$ & 0.204 \\
\hline $\mathrm{BMI}, \mathrm{kg} / \mathrm{m} 2$ & $29.27 \pm 2.29(25-33)$ & $27.10 \pm 4.25(20-33)$ & 0.134 \\
\hline Follow-up, months & $60.73 \pm 7.48(50-74)$ & $58.77 \pm 7.38(50-72)$ & 0.503 \\
\hline Gender, male/female & $6 / 9$ & $7 / 6$ & \\
\hline \multicolumn{4}{|l|}{ Etiology } \\
\hline Component loosening & 6 & 7 & \\
\hline Pain & 4 & 3 & \\
\hline Infection & 3 & 3 & \\
\hline Dislocation & 2 & 0 & \\
\hline BMI: Body Mass Index & & & \\
\hline
\end{tabular}

\begin{tabular}{|c|c|c|c|c|c|c|}
\hline & \multicolumn{2}{|l|}{ Pre-operative ROM } & \multirow{2}{*}{$P$ values } & \multicolumn{2}{|c|}{ ROM at last control visit } & \multirow{2}{*}{$\mathrm{P}$ values } \\
\hline & Constrained & Non-constrained & & Constrained & Non-constrained & \\
\hline Flexion & $57 \pm 12(40-80)$ & $59 \pm 9(45-75)$ & 0.710 & $78 \pm 15(50-95)$ & $75 \pm 14(50-100)$ & 0.342 \\
\hline Abduction & $31 \pm 6(20-45)$ & $35 \pm 6(25-50)$ & 0.060 & $43 \pm 4(35-50)$ & $40 \pm 6(30-50)$ & 0.217 \\
\hline Adduction & $27 \pm 6(20-40)$ & $25 \pm 5(15-35)$ & 0.297 & $28 \pm 3(25-35)$ & $26 \pm 5(20-35)$ & 0.192 \\
\hline ER & $23 \pm 7(10-40)$ & $27 \pm 11(10-45)$ & 0.140 & $30 \pm 7(20-45)$ & $30 \pm 12(10-45)$ & 0.869 \\
\hline IR & $12 \pm 7(5-25)$ & $11 \pm 6(5-25)$ & 0.833 & $19 \pm 8(10-30)$ & $17 \pm 6(10-30)$ & 0.493 \\
\hline Total & $151 \pm 20(115-175)$ & $157 \pm 23(115-180)$ & 0.678 & $199 \pm 20(155-235)$ & $187 \pm 16(165-225)$ & 0.057 \\
\hline
\end{tabular}

$48^{\circ} \pm 6^{\circ}$ (range, $40-60^{\circ}$ ) in the constrained group and $47^{\circ} \pm 4^{\circ}$ (range, $\left.42^{\circ}-55^{\circ}\right)$ in the non-constrained group $(p=0.769)$. Mean post-operative avarage acetabular anteversion angle was $19^{\circ} \pm 4^{\circ}$ (range, $12-24^{\circ}$ ) in the constrained group and $18^{\circ} \pm 8^{\circ}$ (range, $6^{\circ}-26^{\circ}$ ) in the non-constrained group ( $\left.p=0.747\right)$. There was no significant difference between groups.

None of our patients had pain at the end of the ROM, none of them suffered about a sense of impingement, blockade or elastical fixation. Also, none of our patients had radiolucent line around the components occupying more than $50 \%$ of the prosthesis-bone interface on any radiograph or none of our patients were with progressive radiolucent line suggesting loosening or implant wear.

At follow-up period no patient underwent re-revision in neither constrained nor non-constrained group. No dislocation, infection or loosening of the components occured.

\section{Discussion}

In surgical treatment of instability, constrained acetabular components are frequently used in revision hip arthroplasty. The reasons why surgeons avoid constrained acetabular components are the concern of an increased rate of loosening possibly due to impingement and the concern of decreased range of motion [10-14]. But although the use of constrained acetabular inserts rapidly increased in recent years, almost there is no study evaluating ROM of constrained devicesin vivo.
The aim of our study was to compare constrained acetabular components with non-constrained ones in terms of hip ROM and functional outcomes.

Theoretically, the freedom constrained acetabular inserts provide $110^{\circ} \mathrm{ROM}$ with a standart $36 \mathrm{~mm}$ femoral head which is the only available femoral head option, whereas, neutral non-constrained acetabular inserts give $136^{\circ} \mathrm{ROM}$ with $36 \mathrm{~mm}$ femoral head $[17,18]$. However actually fibrous adhesions can occur in most patients and one cannot use maximum ROM allowed by liner. Our results has shown that constrained acetabular components doesn't have lesser range of motions when compared with standard non-constrained components in vivo.

There are a lot of clinical studies related with survival of constrained devices. Studies reported that constrained devices have good short to medium term and poor long term survival rates [19-25]. Poor long term results are attributed ROM limitation of constrained acetabular components in literature [10-14]. But these results may be a result of implant selection bias, because constrained devices may have utilized in more difficult revision cases [23]. In our clinical study, ROMs of constrained patient group was not lesser than non-constrained group.

After revision hip arthroplasty, complications may occur for a variety of reasons. Springer et al. reported complication rate requiring re-revision was 13\% (141 of 1100 patients) with a mean follow-up period of 6 years after revision surgery. These 
complications were instability, aseptic loosening, osteolysis/ wear, deep periprosthetic infection and periprostethic fracture [4]. In our study, no major complication occured at 28 patients with a mean follow-up period of 60 months and there was no significant difference between groups in terms of complications.

To our knowledge, this is the first study comparing in vivo ROMs of constrained acetabular inserts with non-constrained ones. In this study there are two prominent limitations. First, the patient cohort was small. Second, though follow-up period was sufficient for analysing ROM, it was short for analysing long term survival rates.

\section{Conclusion}

Findings of the current study indicated that hip ROMs and functional results in patients with constrained acetabular inserts are not inferior than the patients with non-constrained inserts. Further studies with larger series are wanted to support the results of this work.

\section{Declaration of conflict of interest}

This research received no specific grant from any funding agency in the public, commercial, or not-for-profit sectors. The authors declare that there is no conflict of interest.

\section{References}

1. Vikas K. Total Hip Arthroplasty in 2017 - Current Concepts and Recent Advances. Indian J Orthop 2017; 51: 357-58.

2. Karam JA, Tokarski AT, Ciccotti M, et al. Revision total hip arthroplasty in younger patients: indications, reasons for failure, and survivorship. Phys Sportsmed 2012; 40: 96-101.

3. Rogers $M$, Blom AW, Barnett A, et al. Revision for recurrent dislocation of total hip replacement. Hip Int 2009; 19: 109-13.

4. Springer BD, Fehring TK, Griffin WL, et al. Why Revision Total Hip Arthroplasty Fails. Clin Orthop Relat Res 2009; 467: 166-73.

5. Parvizi J, Picinic E, Sharkey PF. Revision total hip arthroplasty for instability: surgical techniques and principles. Instr Course Lect 2009; 58: 183-91.

6. Brian CW, Thomas EB. Instability after total hip arthroplasty. World J Orthop 2012; 3: 122-30.

7. Mohammed R, Hayward K, Mulay S, et al. Outcomes of dualmobility acetabular cup for instability in primary and revision total hip arthroplasty. J Orthop Traumatol 2015; 16: 9-13.

8. Su EP, Pellicci PM. The role of constrained liners in total hip arthroplasty. Clin Orthop Relat Res 2004; 420: 122-9.

9. Lachiewicz PF, Kelley SS. The use of constrained components in total hip arthroplasty. J Am Acad Orthop Surg 2002; 10: 233-8.

10. Pace $T$, Finley $S$, Snider $R$, et al. Short-term results of novel constrained total hip arthroplasty Orthop Rev (Pavia) 2015; 7: 5779.
11. John TW, Phillip SR, Susannah C. Constrained components for the unstable hip following total hip arthroplasty: a literature review. Int Orthop 2007; 31: 273-7.

12. Maximillian S, Harry ER, William M. Dislocation after total hip arthroplasty. J Am Acad Orthop Surg 2004; 12: 314-21.

13. Noble PC, Durrani SK, Usrey MM. Constrained cups appear incapable of meeting the demands of revision THA. Clin Orthop Relat Res 2012; 470: 1907-16.

14. Donaldson T, Clarke IC. Successes and failures of a freedom constrained cup used in a major salvage procedure. Reconstructive Review 2017; 7.

15. Nomura $T$, Naito $M$, Nakamura $Y$, et al. An analysis of the best method for evaluating anteversion of the acetabular component after total hip replacement on plain radiographs. Bone Joint J 2014; 96: 597-603

16. Shrader MW, Parvizi J, Lewallen DG. The use of a constrained acetabular component to treat instability after total hip arthroplasty. J Bone Joint Surg 2003; 85: 2179-83

17. Karvonen $\mathbf{M}$, Karvonen $H$, Seppanen $M$, et al. Freedom constrained liner for the treatment and prevention of dislocation in total hip arthroplasty. Scand J Surg 2017; 106: 165-72.

18. Luigi Z, Roberto GC. Ceramic-ceramic coupling with big heads: clinical outcome. Eur J Orthop Surg Traumatol 2007; 17: 247-51.

19. Hernigou P, Filippini P. Constrained liner in neurologic or cognitively impaired patients undergoing primary THA. Clin Orthop Relat Res 2010; 468: 3255-62.

20. Ewan B, Michael RW, Gordon C. The Medium Term Outcome of the Omnifit constrained acetabular cup. Hip Int 2012; 22: 505-10.

21. Gill K, Whitehouse SL, Hubble Mj, et al. Short-term results with a constrained acetabular liner in patients at high risk of dislocation after primary total hip arthroplasty. Hip Int 2016; 26: 580-84.

22. Rady $A E$, Asal MK, Bassiony AA. The use of a constrained cementless acetabular component for instability in total hip replacement. Hip Int 2010; 20: 434-9.

23. Lewis PL, Graves SE, de Steiger RN, et al. Constrained Acetabular Components Used in Revision Total Hip Arthroplasty: A Registry Analysis. J Arthroplasty 2017; 32: 3102-07.

24. Berend KR, Lombardi AV Jr, Mallory TH, et al. The longterm outctome of 755 consecutive constrained acetabular components in total hip arthroplasty examining the successes and failures. J Arthroplasty 2005; 20: 93-102.

25. Bremner BR, Goetz DD, Callaghan JJ, et a. Use of constrained acetabular components for hip instability: an average 10-year follow-up study. J Arthroplasty 2003; 18: 131-7. 